DOI: https://doi.org/10.47405/mjssh.v5i12.653

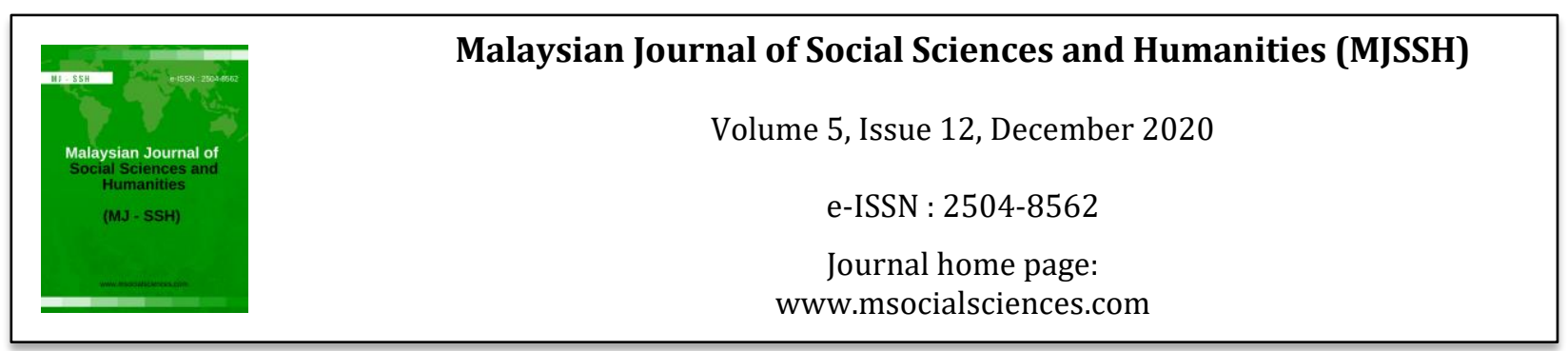

\title{
Persepsi Guru terhadap Penerapan Kemahiran Pemikiran Sejarah dalam Pengajaran dan Pembelajaran Berasaskan Sumber
}

\author{
M. Kaviza ${ }^{1}$ \\ ${ }_{1}^{1}$ Pusat Pengajian Pendidikan dan Bahasa Moden, Universiti Utara Malaysia (UUM) \\ Correspondence: M. Kaviza (kavizakaviza@yahoo.com)
}

\begin{abstract}
Abstrak
Kajian secara deskriptif ini bertujuan untuk mengenal pasti persepsi guru terhadap penerapan kemahiran pemikiran sejarah dan kelima-lima konstruk iaitu kemahiran memahami kronologi, kemahiran meneroka bukti, kemahiran membuat interpretasi, kemahiran membuat imaginasi dan kemahiran membuat rasionalisasi dalam pengajaran dan pembelajaran berasaskan sumber. Empat orang guru sejarah terlibat dalam kajian ini. Soal selidik merupakan instrumen kajian ini. Data kajian ini dianalisis secara deskriptif iaitu min dan sisihan piawai. Dapatan kajian ini menunjukkan bahawa tahap persepsi guru terhadap penerapan kemahiran pemikiran sejarah dalam pengajaran dan pembelajaran berasaskan sumber berada pada tahap tinggi. Tambahan pula, kelima-lima konstruk dalam kemahiran pemikiran sejarah juga berada pada tahap tinggi dalam kalangan guru dalam kajian ini. Kajian ini telah menyediakan sumber maklumat kepada para guru sejarah untuk menerapkan kemahiran pemikiran sejarah yang berkesan dalam proses pengajaran dan pembelajaran.
\end{abstract}

Kata kunci: kemahiran pemikiran sejarah, guru sejarah, pengajaran dan pembelajaran berasaskan sumber

\section{Teachers' Perception of the Inculcating of Historical Thinking Skills in Source-based Teaching and Learning}

\begin{abstract}
The descriptive study aims to identify teachers' perceptions of the application of historical thinking skills and their five constructs, such as chronology, exploration evidence, interpretation, imagination and rationalization skills in source-based teaching and learning. The four history teachers involved in this study. The questionnaire is an instrument of this study. The data of this study were analyzed descriptively, such as mean and standard deviation. The findings of this study indicated that the level of teachers' perception of inculcating of historical thinking skills in source-based teaching and learning at high level. Beside that, the five construct of the historical thinking skills also at high level among teachers in this study. This study suggested to history teachers to inculcate of the historical thinking skills in the teaching and learning process effectively.
\end{abstract}

Keywords: Historical thinking skills, history teacher, source-based teaching and learning 


\section{Pengenalan}

Oleh kerana mata pelajaran sejarah bermatlamat untuk melahirkan generasi yang mempunyai semangat perpaduan, perasaan kekitaan, kesedaran kebangsaan dan memperkukuhkan perasaan cinta akan negara (Pusat Perkembangan Kurikulum [PPK], 2018), maka proses pengajaran dan pembelajaran mata pelajaran sejarah perlulah menekankan kepada peningkatan daya pemikiran dan kematangan murid yang membolehkan mereka mampu untuk berfikir secara kritis dan kreatif serta bertindak secara rasional (Kementerian Pendidikan Malaysia [KPM], 2013). Sehubungan dengan itu, bagi mencapai peningkatan daya dan tahap pemikiran kritis dan kreatif seperti yang disarankan, maka penerapan kemahiran pemikiran sejarah yang terdiri daripada kemahiran memahami kronologi, kemahiran meneroka bukti, kemahiran membuat interpretasi, kemahiran membuat imaginasi dan kemahiran membuat rasionalisasi yang merupakan antara elemen utama dalam kurikulum sejarah yang perlu dilaksanakan dalam proses pengajaran dan pembelajaran (PPK, 2018). Hal ini kerana kemahiran pemikiran sejarah dapat membolehkan murid-murid berfikir disebalik peristiwa sejarah yang terlah berlaku dan memahami kandungan ilmu sejarah dengan lebih mendalam serta membolehkan mereka dapat menganalisis, merumus dan menilai fakta sejarah dengan kritis (Siti Hawa \& Aini, 2007; PPK, 2018; Rosy, 2015; Siti Hawa, 2009). Rentetan daripada itu, pengajaran dan pembelajaran berasaskan sumber telah memberikan suatu dimensi baharu dalam mata pelajaran sejarah dengan menyediakan peluang dan ruang pengajaran dan pembelajaran sejarah yang mendalam berasaskan analisis sumbersumber sejarah di dalam kelas (Cowgill \& Waring, 2017; Dutt-Doner, Cook-Cottone \& Allen, 2007; Nokes, 2014; Reisman, 2012; Patterson, Lucas \& Kithinji, 2012; Kaviza, 2020). Pengajaran dan pembelajaran berasaskan sumber adalah relevan dan bersesuaian dilaksanakan dalam mata pelajaran sejarah oleh guru-guru sejarah. Hal ini disebabkan oleh struktur disiplin ilmu sejarah itu sendiri yang merangkumi elemen penggunaan sumber sejarah bagi membentuk proses pemahaman terhadap kandungan sejarah yang baik (PPK, 2003). Justeru, pelaksanaan pengajaran dan pembelajaran berasaskan sumber bukanlah suatu yang mustahil lagi kepada guru-guru sejarah. Dengan ledakan perkembangan teknologi pendigitalan, guru-guru sejarah dapat memuat turun pelbagai jenis sumber sejarah daripada laman web, portal dan sebagainya berdasarkan tajuk-tajuk sejarah bagi tujuan proses pengajaran dan pembelajaran sejarah di dalam kelas (Alves, 2014; Chassanoff, 2013; Zastrow, 2017).

Sungguhpun begitu, adalah tidak dinafikan bahawa pelaksanaan kaedah pengajaran dan pembelajaran sejarah yang memfokuskan kepada elemen kemahiran pemikiran sejarah masih dipersoalkan dalam kalangan guru walaupun tahap kesediaan penerapan kemahiran pemikiran sejarah dalam proses pengajaran sejarah dalam kalangan guru-guru sejarah dilaporkan berada pada tahap tinggi dan sederhana (Lisa, 2014; Zahara \& Nik Azleena, 2007; Ozmen, 2015). Hal ini demikian kerana penerapan guru terhadap kemahiran pemikiran sejarah yang berkesan dalam proses pengajaran dan pembelajaran sejarah mampu untuk meningkatkan penguasaan pengetahuan dan kemahiran yang lebih baik dalam kalangan murid. Justeru, terdapat satu keperluan untuk mengenal pasti tahap penerapan guru-guru terhadap kemahiran pemikiran sejarah dalam pengajaran dan pembelajaran berasaskan sumber yang masih belum diketahui lagi walaupun kajian-kajian lepas telah memfokuskan elemen kemahiran pemikiran sejarah melalui penggunaan sumber digital sejarah, sumber dokumen teks serta teknologi maklumat dan komunikasi dalam kalangan murid dan guru pelatih (Renuka, Norizan \& Siti Hawa, 2014; Shakila, 2015; Siti Kisni \& Christina, 2019; Bickford II \& Bickford, 2015). Maka, kajian ini adalah bertujuan untuk mengenal pasti tahap penerapan kemahiran pemikiran sejarah dalam pengajaran dan pembelajaran berasaskan sumber dalam kalangan guru sejarah.

\section{Objektif Kajian}

Objektif kajian ini ialah:

i. Mengenal pasti tahap penerapan kemahiran pemikiran sejarah dan konstruknya iaitu memahami kronologi, meneroka bukti, membuat interpretasi, membuat imaginasi dan membuat rasionalisasi dalam pengajaran dan pembelajaran berasaskan sumber. 


\section{Persoalan Kajian}

Persoalan kajian ini ialah:

i. Apakah tahap penerapan kemahiran pemikiran sejarah dan konstruknya iaitu memahami kronologi, meneroka bukti, membuat interpretasi, membuat imaginasi dan membuat rasionalisasi dalam proses pengajaran dan pembelajaran berasaskan sumber?

\section{Metod Kajian}

Kajian berbentuk deskriptif dengan menggunakan soal selidik adalah bertujuan untuk mendapatkan persepsi guru terhadap penerapan kemahiran pemikiran sejarah dalam pengajaran dan pembelajaran berasaskan sumber. Seramai empat orang guru berdasarkan teknik persampelan bertujuan terlibat dalam kajian ini dan guru-guru tersebut telah menjalankan pengajaran dan pembelajaran berasaskan sumber. Instrumen kajian ini merupakan soal selidik penerapan kemahiran pemikiran sejarah yang diadaptasi, disahkan oleh pakar penilai yang berpengalaman dan mempunyai nilai kebolehpercayaan (Cronbach Alpha $=0.92$ ) yang baik dan diterima bagi tujuan kajian ini (Nunnally, 1978). Data kajian ini dianalisis secara deskriptif iaitu min dan sisihan piawai. Tahap interpretasi min dalam kajian ini dilakukan berdasarkan tiga tahap yang diadaptasi daripada kajian Jamil (2002) seperti yang ditunjukkan pada Jadual 1.

Jadual 1: Interpretasi Tahap Penerapan Kemahiran Pemikiran Sejarah

\begin{tabular}{cc}
\hline Skor Min & Tahap \\
\hline $1.00-2.33$ & Rendah \\
$2.34-3.66$ & Sederhana \\
$3.67-5.00$ & Tinggi \\
\hline
\end{tabular}

Sumber: Adaptasi daripada Jamil (2002)

\section{Dapatan Kajian}

\section{Penerapan Kemahiran Pemikiran Sejarah}

Berdasarkan Jadual 2, tahap penerapan kemahiran pemikiran sejarah $(M=4.10, S D=0.35)$ berada pada tahap tinggi. Tambahan pula, keempat-empat orang guru dalam kajian telah melaporkan bahawa tahap penerapan kemahiran pemikiran sejarah adalah tinggi iaitu Guru A $(M=4.32)$, Guru B $(M=3.82)$, Guru C $(M=3.79)$ dan Guru D $(M=4.47)$ seperti ditunjukkan pada Jadual 3. Justeru, dapat dirumuskan bahawa tahap penerapan kemahiran pemikiran sejarah dalam pengajaran dan pembelajaran berasaskan sumber adalah tinggi dalam kajian ini.

Jadual 2: Min Penerapan Kemahiran Pemikiran Sejarah

\begin{tabular}{lccc}
\hline & Min & Sisihan Piawai & Tahap \\
\hline Kemahiran pemikiran sejarah & 4.10 & 0.35 & Tinggi \\
\hline
\end{tabular}

Jadual 3: Min Penerapan Kemahiran Pemikiran Sejarah Berdasarkan Persepsi Guru

\begin{tabular}{ccc}
\hline Guru & Min & Tahap \\
\hline Guru A & 4.32 & Tinggi \\
Guru B & 3.82 & Tinggi \\
Guru C & 3.79 & Tinggi \\
Guru D & 4.47 & Tinggi \\
\hline
\end{tabular}


DOI: https://doi.org/10.47405/mjssh.v5i12.653

Graf 1: Penerapan Kemahiran Pemikiran Sejarah Berdasarkan Persepsi Guru

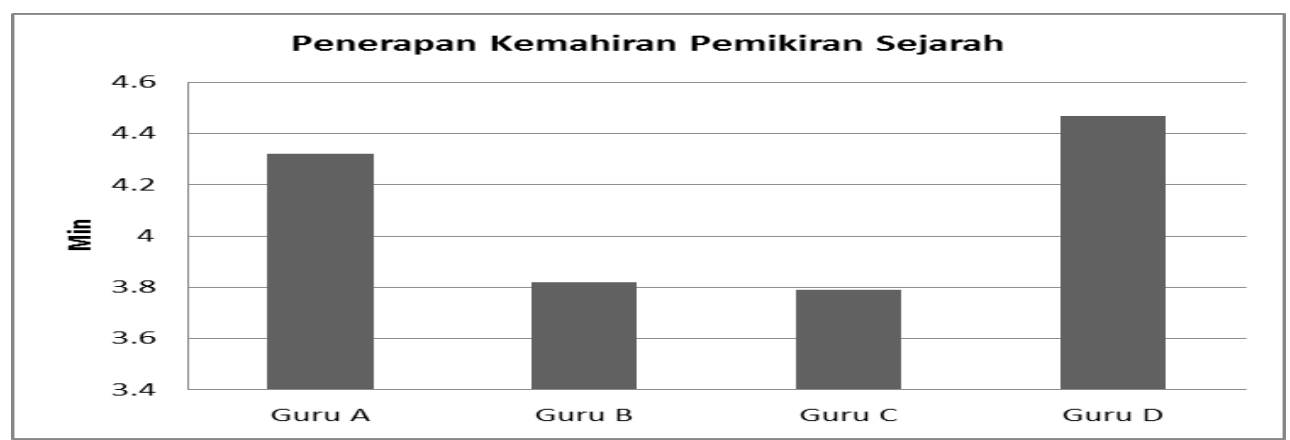

\section{Penerapan Kemahiran Memahami Kronologi}

Berdasarkan Jadual 4, tahap penerapan kemahiran membuat kronologi $(M=4.10, S D=0.34)$ berada pada tahap tinggi. Tambahan pula, keempat-empat orang guru dalam kajian ini telah melaporkan bahawa tahap penerapan kemahiran memahami kronologi adalah tinggi iaitu Guru A ( $M=4.43)$, Guru B $(M=4.00)$, Guru C $(M=4.00)$ dan Guru D $(M=4.57)$ seperti ditunjukkan pada Jadual 5. Justeru, dapat dirumuskan bahawa tahap penerapan kemahiran memahami kronologi dalam pengajaran dan pembelajaran berasaskan sumber adalah tinggi dalam kajian ini.

Jadual 4: Min Penerapan Kemahiran Memahami Kronologi

\begin{tabular}{lccc}
\hline & Min & Sisihan Piawai & Tahap \\
\hline Kemahiran memahami kronologi & 4.10 & 0.34 & Tinggi \\
\hline
\end{tabular}

Jadual 5: Min Penerapan Kemahiran Memahami Kronologi Berdasarkan Persepsi Guru

\begin{tabular}{ccc}
\hline Guru & Min & Tahap \\
\hline Guru A & 4.43 & Tinggi \\
Guru B & 4.00 & Tinggi \\
Guru C & 4.00 & Tinggi \\
Guru D & 4.57 & Tinggi \\
\hline
\end{tabular}

Graf 2: Penerapan Kemahiran Memahami Kronologi Berdasarkan Persepsi Guru

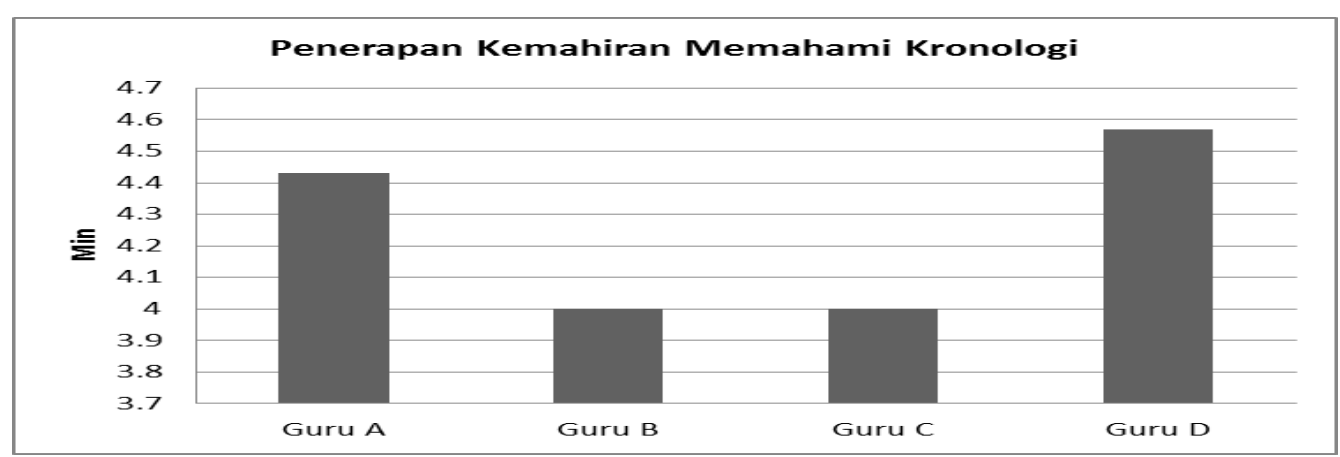

\section{Penerapan Kemahiran Meneroka Bukti}

Berdasarkan Jadual 6, tahap penerapan kemahiran meneroka bukti $(M=4.25, S D=0.29)$ berada pada tahap tinggi. Tambahan pula, tiga orang guru dalam kajian ini telah melaporkan bahawa tahap penerapan kemahiran meneroka bukti adalah tinggi iaitu Guru A $(M=3.88)$, Guru B $(M=3.75)$, Guru C 
$(M=4.00)$, manakala hanya seorang guru sahaja yang telah melaporkan tahap penerapan yang sederhana iaitu Guru D $(M=3.63)$ seperti ditunjukkan pada Jadual 7. Justeru, dapat dirumuskan bahawa tahap penerapan kemahiran meneroka bukti dalam pengajaran dan pembelajaran berasaskan sumber adalah tinggi dalam kajian ini.

Jadual 6: Min Penerapan Kemahiran Meneroka Bukti

\begin{tabular}{lccc}
\hline & Min & Sisihan Piawai & Tahap \\
\hline Kemahiran meneroka bukti & 4.25 & 0.29 & Tinggi \\
\hline
\end{tabular}

Jadual 7: Min Penerapan Kemahiran Meneroka bukti Berdasarkan Persepsi Guru

\begin{tabular}{ccc}
\hline Guru & Min & Tahap \\
\hline Guru A & 3.88 & Tinggi \\
Guru B & 3.75 & Tinggi \\
Guru C & 4.00 & Tinggi \\
Guru D & 3.63 & Sederhana \\
\hline
\end{tabular}

Graf 3: Penerapan Kemahiran Meneroka Bukti Berdasarkan Persepsi Guru

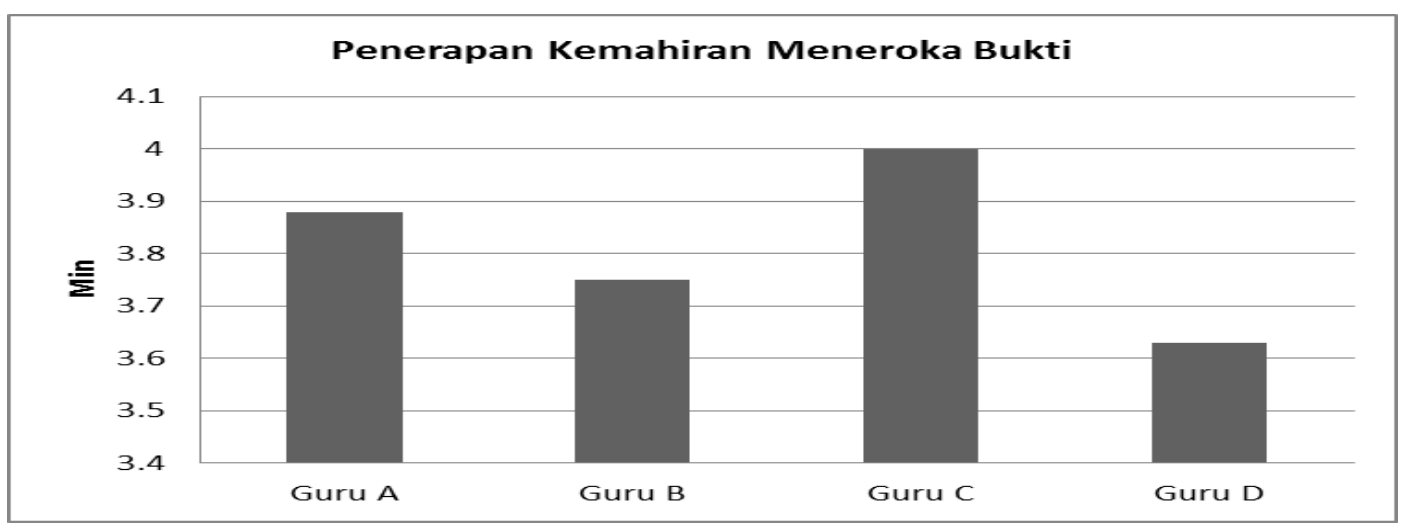

\section{Penerapan Kemahiran Membuat Interpretasi}

Berdasarkan Jadual 8, tahap penerapan kemahiran membuat interpretasi $(M=3.81, S D=0.16)$ berada pada tahap tinggi. Tambahan pula, keempat-empat orang guru dalam kajian ini telah melaporkan bahawa tahap penerapan kemahiran membuat interpretasi adalah tinggi iaitu Guru A $(M=4.60)$, Guru B $(M=4.00)$, Guru C $(M=3.80)$ dan Guru D $(M=3.60)$ seperti ditunjukkan pada Jadual 9. Justeru, dapat dirumuskan bahawa tahap penerapan kemahiran membuat interpretasi dalam pengajaran dan pembelajaran berasaskan sumber adalah tinggi dalam kajian ini.

Jadual 8: Min Penerapan Kemahiran Membuat Interpretasi

\begin{tabular}{llccc}
\hline & Min & Sisihan Piawai & Tahap \\
\hline $\begin{array}{l}\text { Kemahiran } \\
\text { interpretasi }\end{array}$ & membuat & 3.81 & 0.16 & Tinggi \\
\hline
\end{tabular}

Jadual 9: Min Penerapan Kemahiran Membuat Interpretasi Berdasarkan Persepsi Guru

\begin{tabular}{ccc}
\hline Guru & Min & Tahap \\
\hline Guru A & 4.60 & Tinggi \\
Guru B & 4.00 & Tinggi \\
\hline
\end{tabular}



DOI: https://doi.org/10.47405/mjssh.v5i12.653

\begin{tabular}{ccc}
\hline Guru C & 3.80 & Tinggi \\
Guru D & 4.60 & Tinggi \\
\hline
\end{tabular}

Graf 4: Penerapan Kemahiran Membuat Interpretasi Berdasarkan Persepsi Guru

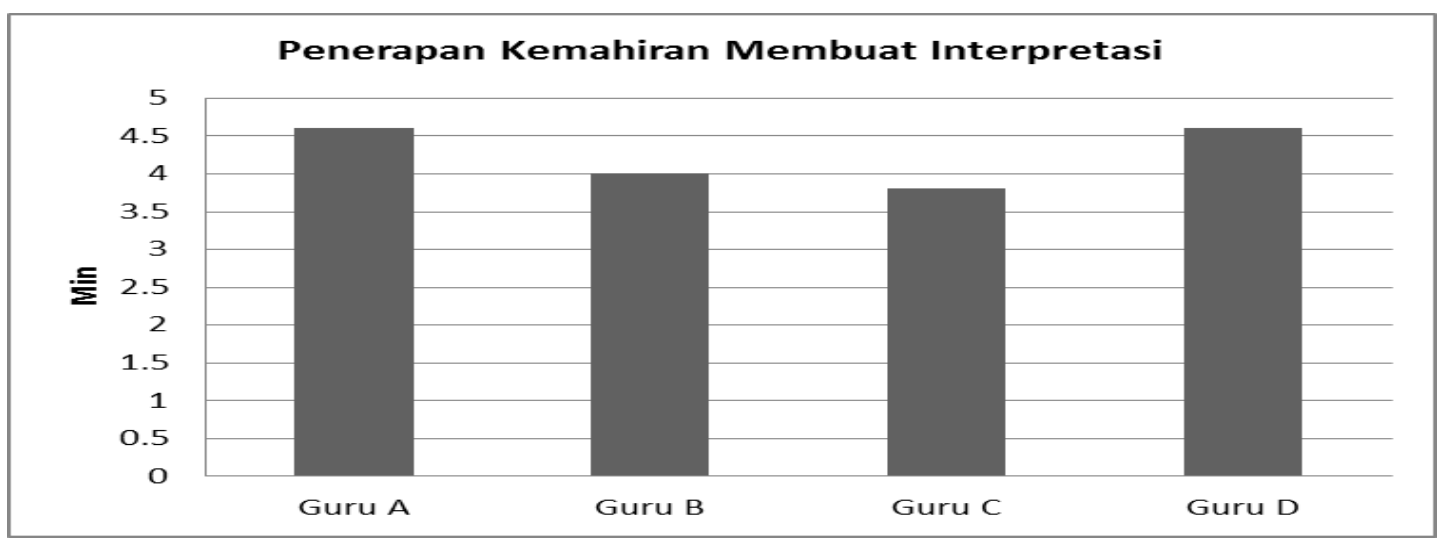

\section{Penerapan Kemahiran Membuat Imaginasi}

Berdasarkan Jadual 10, tahap penerapan kemahiran membuat interpretasi $(M=4.25, S D=0.41)$ berada pada tahap tinggi. Tambahan pula, keempat-empat orang guru dalam kajian ini telah melaporkan bahawa tahap penerapan kemahiran membuat imaginasi adalah tinggi iaitu Guru A $(M=4.50)$, Guru B $(M=3.83)$, Guru C $(M=4.00)$ dan Guru D $(M=5.00)$ seperti ditunjukkan pada Jadual 11. Justeru, dapat dirumuskan bahawa tahap penerapan kemahiran membuat imaginasi dalam pengajaran dan pembelajaran berasaskan sumber adalah tinggi dalam kajian ini.

Jadual 10: Min Penerapan Kemahiran Membuat Imaginasi

\begin{tabular}{lcccc}
\hline & & Min & Sisihan Piawai & Tahap \\
\hline $\begin{array}{l}\text { Kemahiran } \\
\text { imaginasi }\end{array}$ & membuat & 4.25 & 0.41 & Tinggi \\
\hline
\end{tabular}

Jadual 11: Min Penerapan Kemahiran Membuat Imaginasi Berdasarkan Persepsi Guru

\begin{tabular}{ccc}
\hline Guru & Min & Tahap \\
\hline Guru A & 4.50 & Tinggi \\
Guru B & 3.83 & Tinggi \\
Guru C & 4.00 & Tinggi \\
Guru D & 5.00 & Tinggi \\
\hline
\end{tabular}

Graf 5: Penerapan Kemahiran Membuat Imaginasi Berdasarkan Persepsi Guru

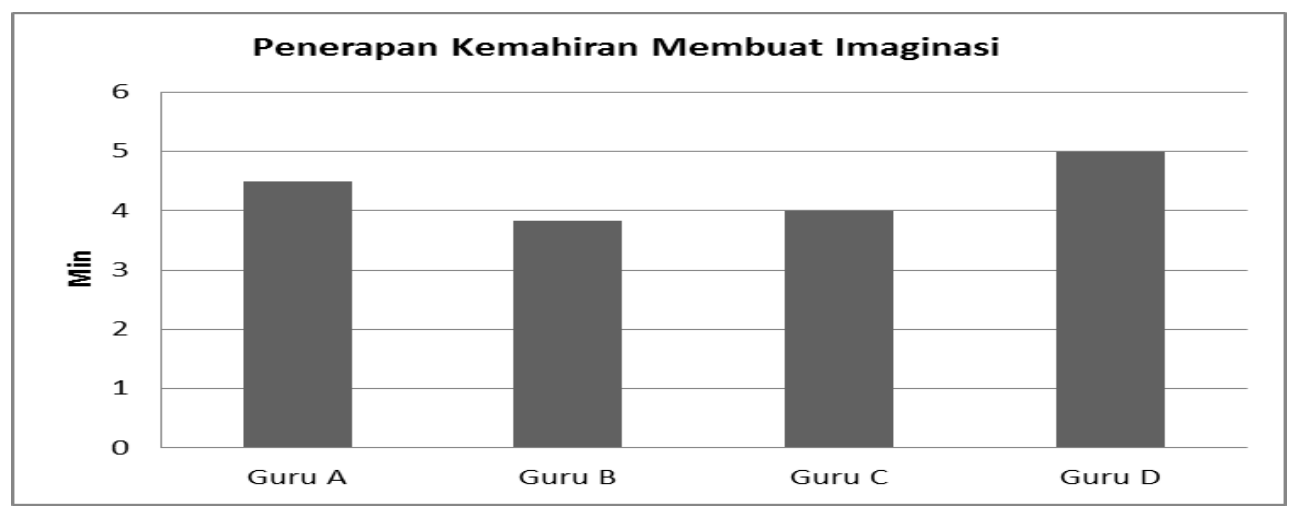




\section{Penerapan Kemahiran Membuat Rasionalisasi}

Berdasarkan Jadual 12, tahap penerapan kemahiran membuat rasionalisasi $(M=4.00, S D=0.68)$ berada pada tahap tinggi. Tambahan pula, hanya dua orang guru dalam kajian ini telah melaporkan bahawa tahap penerapan kemahiran membuat rasionalisasi adalah tinggi iaitu Guru A $(M=4.38)$ dan Guru D $(M=4.75)$, manakala dua orang guru lagi telah melaporkan tahap penerapan yang sederhana iaitu Guru B $(M=3.63)$ dan Guru C $(M=3.25)$ seperti ditunjukkan pada Jadual 13. Justeru, dapat dirumuskan bahawa tahap penerapan kemahiran membuat rasionalisasi dalam pengajaran dan pembelajaran berasaskan sumber adalah tinggi dalam kajian ini.

Jadual 12: Min Penerapan Kemahiran Membuat Rasionalisasi

\begin{tabular}{lccc}
\hline & Min & Sisihan Piawai & Tahap \\
\hline $\begin{array}{l}\text { Kemahiran membuat } \\
\text { rasionalisasi }\end{array}$ & 4.00 & 0.68 & Tinggi \\
\hline
\end{tabular}

Jadual 10: Min Penerapan Kemahiran Membuat Rasionalisasi Berdasarkan Persepsi Guru

\begin{tabular}{ccc}
\hline Guru & Min & Tahap \\
\hline Guru A & 4.38 & Tinggi \\
Guru B & 3.63 & Sederhana \\
Guru C & 3.25 & Sederhana \\
Guru D & 4.75 & Tinggi \\
\hline
\end{tabular}

Graf 6: Penerapan Kemahiran Membuat Rasionalisasi Berdasarkan Persepsi Guru

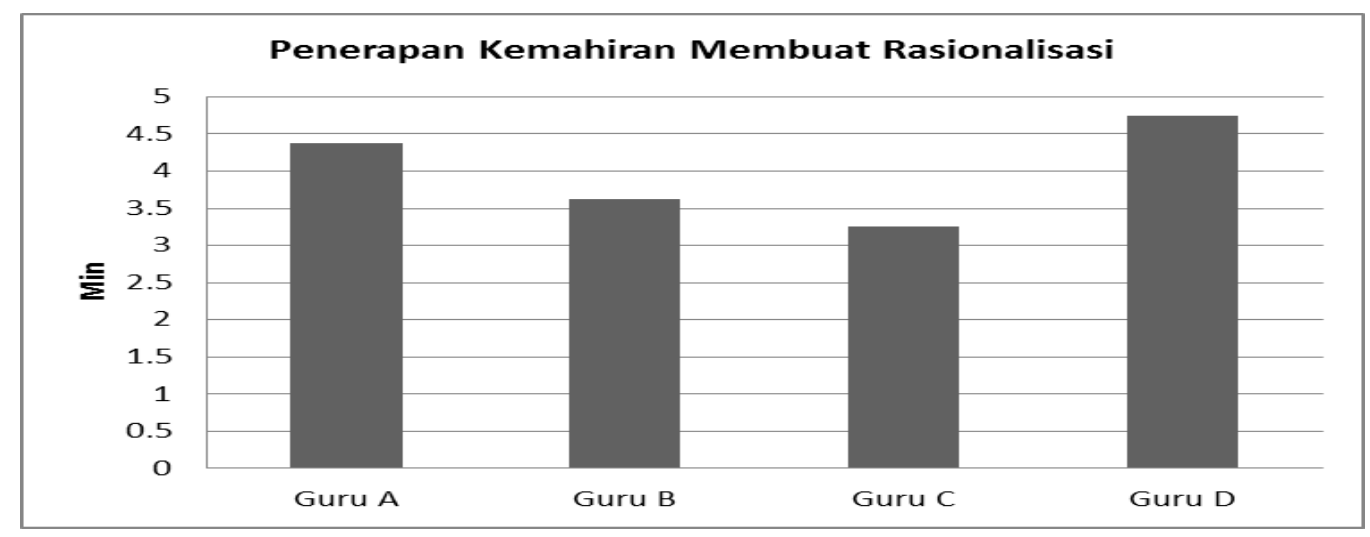

\section{Perbincangan Kajian}

Dapatan kajian ini yang menunjukkan bahawa tahap persepsi guru terhadap penerapan kemahiran pemikiran sejarah dalam pengajaran dan pembelajaran berasaskan sumber yang tinggi adalah sealiran dengan dapatan kajian Clark (2014), Abdul Rahim dan Asmah (2018), Buchanan (2015), Salinas, Bellows dan Liaw (2011), Lee dan Coughlin (2011) serta Baron (2013) yang telah membuktikan bahawa penggunaan filem dokumentari sejarah, peta i-Think, sumber sejarah digital, buku novel grafik bukan fiksyen dan inkuiri terbimbing dalam proses pengajaran dan pembelajaran sejarah dapat meningkatkan amalan kemahiran pemikiran sejarah, di samping dapat meningkatkan pengetahuan kandungan dan pedagogi. Tahap kemahiran pemikiran sejarah yang tinggi yang dilaporkan dalam kajian ini adalah bertepatan dengan dapatan kajian Abdul Razaq (2010) yang telah melaporkan bahawa tahap pengetahuan guru terhadap konsep kemahiran pemikiran sejarah adalah tinggi yang telah memberikan implikasi bahawa guru-guru sejarah berupaya dan mampu untuk mengaplikasikan kemahiran pemikiran tersebut dengan meluas dalam kalangan murid melalui pelaksanaan kaedah dan 
aktiviti pembelajaran seperti penyoalan, perbincangan, inkuiri, multimedia, projek, brainstorming, simulasi, modeling, perdebatan, penceritaan dan analisis dokumen secara efisien di dalam kelas. Tambahan pula, dapatan kajian Kaviza (2019) yang telah melaporkan bahawa tahap kompetensi guru dalam penggunaan sumber sejarah telah menyumbang sebanyak 57 peratus terhadap penerapan kemahiran pemikiran sejarah dan dapatan kajian Izhab dan Muhammad Zaid (2018) yang turut melaporkan bahawa amalan pengajaran sejarah telah menunjukkan terdapat peningkatan sebanyak 3.74 peratus terhadap penerapan kemahiran pemikiran sejarah dan kedua-dua dapatan kajian tersebut telah menyokong dapatan kajian ini secara langsung mahupun secara tidak langsung. Selain itu, tahap kemahiran memahami kronologi, kemahiran meneroka bukti, kemahiran membuat interpretasi, kemahiran membuat imaginasi dan kemahiran membuat rasionalisasi yang dilaporkan berada pada tahap tinggi melalui pengajaran dan pembelajaran berasaskan sumber dalam kajian ini adalah bertepatan dengan dapatan kajian Muhammad Yazid (2018), Sharifah, Noereiny dan Elisabeth (2010), Abdul Rahim dan Asmah (2018), Lee (2012), Baharuddin (2006), Mohd Mahzan, Abdul Razaq, Noria Munirah dan Ahmad Ali (2016), Rully dan Abdul Razaq (2015) dan Shakila dan Nor Hashimah (2016) yang telah melaporkan tahap persepsi, pengetahuan, pelaksanaan dan pengajaran dalam kelimalima konstruk kemahiran pemikiran sejarah seperti kemahiran memahami kronologi, kemahiran meneroka bukti, kemahiran membuat interpretasi, kemahiran membuat imaginasi dan kemahiran membuat rasionalisasi yang berbeza-beza dalam kalangan guru dan guru pelatih dalam bidang pendidikan sejarah.

\section{Kesimpulan}

Kesimpulannya, dapatan kajian ini menunjukkan bahawa tahap kemahiran pemikiran sejarah berada pada tahap tinggi dalam pengajaran dan pembelajaran berasaskan sumber. Implikasi kajian ini telah membuka ruang kepada guru-guru untuk meningkatkan kemahiran pemikiran sejarah yang lebih baik lagi melalui pelaksanaan kaedah pengajaran dan pembelajaran berasaskan sumber kerana guru memainkan peranan sebagai penggerak yang penting dalam membentuk kualiti kemenjadian murid melalui penguasaan komponen kurikulum iaitu pengetahuan, kemahiran dan nilai yang telah disarankan oleh pihak KPM.

\section{Rujukan}

Abdul Rahim Ali \& Asmah Abu Bakar. (2018). Kemahiran pemikiran sejarah melalui penggunaan peta I-Think oleh guru sejarah sekolah menengah. Jurnal Paradigma, 16, 36-54.

Abdul Razaq Ahmad. (2014). Determination of teaching aids and methods to inculcate thinking skills in history subjects. TAWARIKH: International Journal for Historical Studies, 6(1), 1-12.

Alves, D. (2014). Introduction: digital methods and tools for historical research. International Journal of Humanities and Arts Computing, 8(1), 1-12.

Baharuddin Jabar. (2006). Pelaksanaan Kemahiran Pemikiran Sejarah dalam Pengajaran Guru-guru Sejarah: Satu Kajian Kes di daerah Hilir Perak.

Baron, C. (2013). Using inquiry based instruction to encourage teachers' historical thinking at historic sites. Teaching and Teacher Education, 35, 157-169.

Bickford II, J.H., \& Bickford, M.S. (2015). Historical thinking, reading and writing about world's newest nation, South Sudan. Social Studies Research and Practice, 10(2), 111- 123.

Buchanan, L.B. (2015). Fostering historical thinking toward civil rights movement counter-narratives: Documentary film in elementary students. Social Studies, 106, 47-56.

Chassanoff, A. (2013). Historians and the use of primary source materials in the digital age. The American Archivist, 76(2), 458-479.

Clark, J.S. (2014). Teaching historical agency: explicitly connecting past and present with graphic novels. Social Studies Research and Practice, 9(3), 66-80.

Cowgill II, D.A., \& Waring, S.M. (2017). Historical thinking: An evaluation of student and teacher ability to analyze sources. Journal of Social Studies Education Research, 8(1), 115-145. 
Dutt-Doner, K., Cook-Cottone, C., \& Allen, S. (2007). Improving classroom Instruction: Understanding the developmental nature of analyzing primary sources. Research in Middle Level Education, 30(6), 1-20.

Izhab Ismail \& Mohamad Zaid Ismail. (2018). Hubungan Kemahiran Pemikiran Sejarah dengan Amalan Guru dalam Pengajaran dan Pembelajaran Sejarah. Prosiding Seminar Kebangsaan Majlis Dekan Pendidikan Universiti Awam, 303-319.

Kaviza, M. (2019). Hubungan antara kompetensi guru sejarah dalam penggunaan sumber sejarah dan penerapan kemahiran pemikiran sejarah. e-Bangi: Journal of Social Science and Humanities, 16(1), 1-13.

Kaviza, M. (2020). Penggunaan sumber dokumen teks dalam subjek sejarah: satu sorotan kajian. Malaysian Journal of Social Sciences and Humanities, 5(10), 200-206.

Kementerian Pendidikan Malaysia. (2013). Pelan Pembangunan Pendidikan Malaysia 2013-2025. Putrajaya: Kementerian Pendidikan Malaysia.

Lee, B.N. (2012). Applying Technical-based Analyzation to historical thinking skills: History teachers review. IRACST - International Journal of Advanced Computing Engineering and Application, $1(3), 78-86$.

Lee, M., \& Coughlin, M. (2011). Developing teacher's ability to make claims about historical significance: A promising practice from a teaching American history grant program. The History Teacher, 44(3), 447-461.

Lisa, Y. S. (2014). Kajian tinjauan kesediaan guru-guru sejarah menerapkan kemahiran pemikiran sejarah dalam kalangan murid-murid. Jurnal Penyelidikan Kent, 13, 37-49.

Mohd Mahzan Awang, Abdul Razaq Ahmad, Noria Munirah Yakub \& Ahmad Ali Seman. (2016). Historical Thinking Skills among Pre-Service Teachers in Indonesia and Malaysia. Creative Education, 7, 62-76.

Muhammad Yazid Khalil (2018). Tahap Pengetahuan Guru Sejarah Sekolah Rendah Dalam Kemahiran Pemikiran Sejarah (KPS). Prosiding National Innovation and Invention Competition through Exhibition (iCompEx2018), 1-12.

Nokes, J.D. (2014). Elementary students' roles and epistemic stances during document based history lessons. Theory \& Research in Social Education, 42, 375-413.

Ozmen, C. (2015). Social studies teacher candidates' view on historical thinking skills. Education Research and Reviews, 10(14), 2031-2042.

Patterson, N.C., Lucas, A.G., \& Kithinji, M. (2012). Higher order thinking in social studies: An analysis of primary source document use. Social Studies Research and Practice, 7(2), 68-85.

Pusat Perkembangan Kurikulum. (2003). Huraian sukatan pelajaran mata pelajaran sejarah tingkatan empat. Kuala Lumpur: Kementerian Pendidikan Malaysia.

Pusat Perkembangan Kurikulum. (2018). Dokumen standard kurikulum dan pentaksiran mata pelajaran sejarah tingkatan empat dan lima. Putrajaya: Kementerian Pendidikan Malaysia.

Reisman, A. (2012). The "document-based lesson": Bringing disciplinary inquiry into high school history classrooms with adolescent struggling readers. Journal of Curriculum Studies, 44(2), 233264.

Renuka Ramakrishnan, Norizan Esa \& Siti Hawa Abdullah. (2014, Ogos). Kesan Penggunaan Sumber Sejarah Digital Terhadap Kemahiran Pemikiran Sejarah. Kertas kerja yang dibentangkan di $23^{\text {rd }}$ International Conference of Historians of Asia 2014 (IAHA 2014), Kedah, Malaysia.

Rosy Talin. (2015). Historical thinking skills - The forgotten skills? International Journal of Learning and Teaching, 7(1), 15-23.

Rully, P.N.P \& Abdul Razaq Ahmad. (2015). Gaya belajar dan kemahiran pemikiran sejarah dalam pembelajaran sejarah di peringkat universitas. Edusentris: Jurnal Ilmu Pendidikan dan Pengajaran, 2(3), 253-263.

Salinas, C., Bellows, M. E., \& Liaw, H. L. (2011). Pre-service social studies teachers' historical thinking and digitized primary sources: What they use and why. Contemporary Issues in Technology and Teacher Education, 11(2), 184-204.

Shakila Che Dahalan \& Nor Hashimah Hashim. (2016). The implementation of historical thinking skills among teacher trainees in teaching learning process. $5^{\text {th }}$ International Conference on Language, Education and Innovation Proceeding, 211-218 
Shakila Che Dahalan (2015). Kemahiran Pemikiran Sejarah melalui penggunaan teknologi maklumat dan komunikasi (TMK) oleh guru-guru pelatih. Tesis Sarjana Sastera (Pendidikan), Universiti Sains Malaysia.

Sharifah Nor Puteh, Nooreiny Maarof \& Elisabeth Tak. (2010). Students' Perception of the Teaching of Historical Thinking Skills. Pertanika Journal Social Science and Humanities, 18(S), 87-95.

Siti Hawa Abdullah. (2009). Takrif dan Ciri-ciri Pemikiran Sejarah. DP, 9(1), 98-106.

Siti Kisni Kisson \& Christina Peter Ligadu. (2019). Elemen meneroka bukti dalam pembelajaran sejarah menggunakan sumber dokumen teks. Malaysia Journal of Social Sciences and Humanities, 4(8), 54-60.

Zahara Aziz \& Nik Azleena Nik Ismail. (2007). Kajian Tinjauan Kesediaan Guru-guru Sejarah Menerapkan Kemahiran Pemikiran Sejarah kepada Para Pelajar. Jurnal Pendidikan, 32, 119-137.

Zastrow, J. (2017, September). The digital archivist: Archives and activism engaging students with primary sources. InfoToday, 23-27. 